\title{
PERBANDINGAN HASIL PEMERIKSAAN WIDAL TABUNG NEGATIF DENGAN PEMERIKSAAN POLIMERASE CHAIN REACTION (PCR) DALAM MENEGAKAN DIAGNOSA DEMAM TIFOID
}

\author{
Wiwik Dwi Irawati ${ }^{1}$ \\ ${ }^{1}$ Mahasiswa Magister Imunologi, Sekolah Pascasarjana, Universitas Airlangga
}

\begin{abstract}
Comparison of Negative-Tube Widal Examination between Polimerase Chain Reaction (PCR) Examination to Enforcing Tifoid Fever Diagnose. Typhoid fever is a systemic infectious disease caused by Salmonella typhi. This disease can be found in many developing countries. Typhoid fever can be diagnosed clinically and through laboratory tests. The laboratory tests often applied are serological examinations including the Widal test. Another method is PCR (Polymerase Chain Reaction), which is also believed to provide a high diagnostic value to identify Salmonella typhi bacteria. This study aimed to compare the negative-tube examination results between the Widal test and the PCR test in establishing the diagnosis of typhoid fever. This research study is descriptive. Based on the results of the examination on 20 samples of the negative tubes using Salmonella typhi Widal test and PCR test, 12 samples proved positive and 8 samples were negative from Salmonella typhi infection. There were differences in the percentage between negative-tube Widal test and PCR test results. It indicated that the PCR method had a higher sensitivity and specificity compared to the Widal test. The PCR was used only limitedly in research. Thus, it is expected that in the future, PCR can be useful as one of the routine diagnostic tools for typhoid fever.
\end{abstract}

Keywords: Typhoid fever, PCR test, widal test

\begin{abstract}
Abstrak: Perbandingan Hasil Pemeriksaan Widal Tabung Negatif dengan Pemeriksaan Polimerase Chain Reaction (PCR) dalam Menegakkan Diagnosa Demam Tifoid. Demam tifoid merupakan suatu penyakit infeksi sistemik yang disebabkan oleh Salmonella typhi yang masih dijumpai secara luas di berbagai negara berkembang. Penegakan diagnosa demam tifoid dilakukan secara klinis dan melalui pemeriksaan laboratorium. Pemeriksaan laboratorium yang selama ini banyak dilakukan adalah pemeriksaan serologis yaitu tes widal. Metode lain untuk identifikasi bakteri Salmonella typhi yang memiliki nilai diagnostik tinggi adalah PCR (Polimerase Chain Reaction). Penelitian ini bertujuan untuk mengetahui perbandingan hasil pemeriksaan widal tabung negatif dengan pemeriksaan PCR dalam menegakan diagnosa demam tifoid. Jenis penelitian ini adalah deskriptif. Berdasarkan hasil pemeriksaan dari 20 sampel uji Widal tabung negatif setelah dilakukan pemeriksaan PCR Salmonella typhi 12 sampel positif Salmonella typhi dan 8 sampel Salmonella typhi negatif. Dari hasil penelitian ada perbedaan persentase hasil pemeriksaaan uji Widal tabung negatif dengan pemeriksaan PCR, hal ini membuktikan bahwa metode PCR mempunyai sensitifitas dan spesifisitas lebih tinggi dibandingkan dengan uji Widal tabung. Selama ini PCR lebih banyak digunakan terbatas dalam lingkup penelitian diharapkan kedepannya dapat digunakan sebagai salah satu alat diagnostik rutin penyakit demam tifoid.
\end{abstract}

Kata Kunci : Demam tifoid, PCR, widal tabung 


\section{PENDAHULUAN}

Demam tifoid disebabkan oleh bakteri gram negatif Salmonella typhi (World Health Organization, 2003). Sumber infeksi berasal dari individu yang terinfeksi karena mengkonsumsi air atau makanan yang terkontaminasi tetapi juga setelah kontak dengan pasien. Pasien dapat menjadi pembawa bakteri seumur hidup melalui fesesnya dan merupakan faktor penting dalam pemeliharaan patogen pada siklus populasi. Patogen tidak menginfeksi hewan oleh karena itu penularannya hanya dari manusia ke manusia.(Alba, Bakker, Hatta, \& Scheelbeek, 2016) World Health Organization (WHO) telah melakukan upaya dalam mengatasi kasus tifoid dengan mengkombinasikan program pengobatan serta peningkatan kualitas air dan sanitasi.(Crump \& Mintz, 2011) Laporan dari berbagai penelitian melaporkan bahwa penyakit ini menyebabkan 13,5 juta penyakit secara global pada tahun 2010.(Ochiai et al., 2008)'(Buckle, Walker, Black, \& Walker, 2012) Di seluruh dunia, insiden tertinggi terjadinya demam tifoid tercatat di Afrika dan Asia.(Crump \& Mintz, 2011),(Buckle et al., 2012) Di Indonesia, penelitian yang dilakukan di daerah pemukiman kumuh Provinsi DKI Jakarta memperkirakan tingkat kejadian tifoid yaitu berkisar 148,7 per 100000 orang-tahun pada kelompok usia 2-4 tahun, 180,3 pada tahun kelompok usia 5-15 tahun dan 51,2 pada mereka yang berusia di atas 16 tahun, dengan usia rata-rata mulai 10,2 tahun.(Ochiai et al., 2008)

Pada kondisi global WHO memperkirakan terdapat 21 juta kasus terjadinya demam tifoid pertahun dan hal tersebut dapat bertambah mungkin merupakan perkiraan yang rendah karena diagnosa yang buruk. (Crump \& Mintz, 2011)'(Wain \& Hosoglu, 2008) Ada beberapa pilihan untuk mendiagnosis demam enterik, tanda dan gejala klinis, penanda serologis, kultur bakteri, deteksi antigen dan amplifikasi DNA.(Wain \& Hosoglu, 2008) Diagnosis klinis demam tifoid sulit dilakukan karena manifestasi penyakitnya beragam dan ada banyak penyebab demam berkepanjangan di daerah endemis tifoid.(Storey, Huang, Crudder, Golden, \& Santos, 2015)'(Ayub et al., 2015)

Penegakan diagnosis demam tifoid menjadi cukup sulit bila tidak adanya gejala atau tanda yang spesifik. Di daerah endemis, demam lebih dari 1 minggu yang tidak diketahui penyebabnya harus dipertimbangkan sebagai demam tifoid sampai terbukti penyebabnya. Beberapa pemeriksaan penunjang yang sering digunakan untuk mendiagnosis demam tifoid terdiri dari pemeriksaan darah tepi, identifikasi kuman melalui isolasi atau biakan, identifikasi kuman melalui uji serologis, serta identifikasi kuman secara molekuler. Diagnosis pasti demam tifoid ditegakkan bila ditemukan bakteri Salmonella typhi dalam biakan darah, urin, feses, atau sumsum tulang.(Sucipta, 2015)'(Choerunnisa, Tjiptaningrum, \& Basuki, 2014)'(Septiawan, Herawati, \& Yasa, 2013).

Uji serologis digunakan untuk mendeteksi antibodi spesifik terhadap komponen antigen Salmonella typhi maupun mendeteksi antigen itu sendiri. Beberapa uji serologis yang dapat digunakan pada demam tifoid ini diantaranya adalah uji widal dan tes tubex. Uji widal merupakan pemeriksaan yang sering digunakan, namun karena sensitivitas dan spesifitasnya rendah maka uji widal menjadi kurang efektif lagi.(Setiana, 2016)

Diagnosis pasti ditegakkan bila ditemukan adanya kuman S. typhi tetapi terdapat kelemahan seperti waktu yang lama, sulit dilakukan di daerah, adanya penggunaan antibiotika, jumlah bakteri yang sangat minimal, volume spesimen yang tidak mencukupi dan waktu pengambilan spesimen yang tidak tepat. Hal ini menyebabkan beberapa peneliti mulai menganjurkan teknik PCR (Polymerase Chain Reaction). Selain itu, penggunaan sistem pakar juga sudah mulai 
digunakan untuk mendiagnosis demam tifoid.(Marleni, Iriani, \& Tjuandra, 2014)

Tujuan dari penelitian ini adalah untuk mengetahui hasil pemeriksaan widal tabung negatif dibandingkan dengan pemeriksaan PCR (Polimerase Chain Reaction), sehingga hasil dari penelitian ini dapat membantu dalam menegakan diagnosa demam tifoid.

\section{METODE}

Penelitian ini dilaksanakan pada bulan Juli 2018 dan berakhir pada bulan Agustus 2018. Penelitian dilaksanakan di Instalasi Imunologi Balai Besar Laboratorium Kesehatan Surabaya dan Institute Tropical Disease Center Kampus C Universitas Airlangga Surabaya.

Jenis penelitian ini adalah deskriptif dengan rancangan observatif laboratorium yang bersifat crossectional. Dalam penelitian ini terdapat dua variabel yaitu variabel bebas dan variabel terikat. Variabel bebas dalam penelitian ini adalah serum dan darah EDTA sedangkan variabel terikatnya adalah hasil titer Widal negatif dan pemeriksaan PCR.

Dalam pemeriksaan demam tifoid untuk uji widal tabung menggunakan Antigen Salmonella typhi O, H, Paratyphi A dan Paratyphi B dengan metode aglutinasi. Untuk deteksi kuman Salmonella dengan amplifikasi DNA Salmonella metode PCR.

Adapun prinsip pemeriksaan yang digunakan dalam penelitian ini yaitu : Uji Widal Tabung Aglutinasi, yaitu antibodi yang terdapat didalam serum akan berikatan dengan antigen bakteri yang terdapat dalam reagen. Polimerase Chain Reaction (PCR) Penggandaan enzimatik secara cepat pada suatu segmen DNA dilakukan melalui ulangan siklus amplifikasi dengan 3 macam suhu yaitu, suhu Denaturasi untuk pemisahan 2 utas DNA, suhu Anealing untuk melekatnya primer pada DND template dan suhu Polimerase untuk pemanjangan rantai.

Data yang dibutuhkan dalam penelitian ini adalah data primer yang diperoleh dari pengambilan sampel serum dan darah EDTA penderita dengan uji widal negatif yaitu titer $\mathrm{O} \leq$ $1 / 80$. Sampel yang digunakan adalah darah penderita yang dicurigai menderita demam tifoid yang datang ke Instalasi Imunologi Balai Besar Laboratorium Kesehatan Surabaya.

Adapun langkah-langkah metode analisa yang dilakukan dalam penelitian ini yaitu: Pengumpulan data yang meliputi serum dan darah EDTA penderita dengan uji widal negatif yaitu titer $O \leq 1 / 80$. Pemeriksaan serum dan darah EDTA, untuk mengetahui hasil pemeriksaan widal tabung negatif dan pemeriksaan PCR (Polimerase Chain Reaction) yang kemudian hasil kedua metode dibandingkan. Interpretasi hasil dari metode uji widal yaitu: Titer aglutinin $\mathrm{O}$ dan atau $\mathrm{H}$ sesbesar atau sama dengan titer aglutinin yang ditetapkan sebagai titer diagnostik berdasarkan nilai rujukan titer aglutinin, batas rujukan yang ditetapkan titer $1 / 160$ untuk aglutinin $O$ dan $H$ sesuai yang didapatkan. Terdapat peningkatan titer 4 kali atau lebih di hasil pemeriksaan sampel yang diambil selang satu minggu kemudian. Sedangkan interpretasi hasil dari metode Polimerase Chain Reaction (PCR), yaitu adanya pita fragmen DNA pada gel dengan ukuran 137 bp (base pair).

\section{HASIL}

Hasil pemeriksaan Widal Tabung pada 70 sampel darah penderita (suspect demam tifoid), diambil 20 spesimen sebagai sampel dengan titer $\mathrm{O}$ $\leq 1 / 80$, sebagai berikut :

\section{Tabel 1. Hasil pemeriksaan widal} tabung

\begin{tabular}{ccccc}
\hline No. & $\mathrm{O}$ & $\mathrm{H}$ & $\mathrm{PA}$ & $\mathrm{PB}$ \\
\hline 1 & $1 / 80$ & $1 / 80$ & Neg & Neg \\
2 & $1 / 80$ & $1 / 80$ & Neg & Neg \\
3 & $1 / 20$ & $1 / 20$ & Neg & Neg \\
4 & $1 / 40$ & $1 / 40$ & Neg & Neg \\
5 & $1 / 40$ & $1 / 40$ & Neg & Neg \\
6 & $1 / 40$ & $1 / 40$ & Neg & Neg \\
7 & $1 / 80$ & $1 / 80$ & $1 / 160$ & $1 / 80$ \\
8 & $1 / 20$ & Neg & $1 / 20$ & $1 / 20$
\end{tabular}




\begin{tabular}{ccccc}
9 & $1 / 80$ & $1 / 80$ & Neg & Neg \\
10 & $1 / 80$ & $1 / 80$ & Neg & Neg \\
11 & $1 / 80$ & $1 / 160$ & Neg & Neg \\
12 & $1 / 80$ & $1 / 80$ & $1 / 80$ & Neg \\
13 & $1 / 40$ & $1 / 40$ & Neg & $1 / 80$ \\
14 & $1 / 40$ & Neg & Neg & Neg \\
15 & $1 / 20$ & $1 / 40$ & Neg & $1 / 40$ \\
16 & $1 / 40$ & $1 / 160$ & Neg & Neg \\
17 & $1 / 80$ & $1 / 80$ & Neg & Neg \\
18 & $1 / 40$ & $1 / 40$ & Neg & Neg \\
19 & $1 / 40$ & $1 / 40$ & Neg & Neg \\
20 & $1 / 20$ & $1 / 20$ & Neg & Neg \\
\hline
\end{tabular}

Adapun pemeriksaan dengan PCR terhadap 20 sampel titer $O \leq 1 / 80$, sebagai berikut:

Tabel 1. Hasil Pemeriksaan Widal Tabung titer $0 \leq 1 / 80$ dan pemeriksaan PCR

\begin{tabular}{ccc}
\hline No & $\begin{array}{c}\text { Widal } \\
\text { tabung } \\
(\mathbf{O} \leq \mathbf{1} / \mathbf{8 0})\end{array}$ & $\begin{array}{c}\text { PCR } \\
\text { Salmonella } \\
\text { typhi }\end{array}$ \\
\hline 1 & $1 / 80$ & Positif \\
2 & $1 / 80$ & Positif \\
3 & $1 / 20$ & Positif \\
4 & $1 / 40$ & Positif \\
5 & $1 / 40$ & Positif \\
6 & $1 / 40$ & Negatif \\
7 & $1 / 80$ & Negatif \\
8 & $1 / 20$ & Negatif \\
9 & $1 / 80$ & Positif \\
10 & $1 / 80$ & Negatif \\
11 & $1 / 80$ & Positif \\
12 & $1 / 80$ & Positif \\
13 & $1 / 40$ & Negatif \\
14 & $1 / 40$ & Positif \\
15 & $1 / 20$ & Positif \\
16 & $1 / 40$ & Positif \\
17 & $1 / 80$ & Negatif \\
18 & $1 / 40$ & Negatif \\
19 & $1 / 40$ & Negatif \\
20 & $1 / 20$ & Positif \\
\hline
\end{tabular}

Berdasarkan hasil pemeriksaan 20 sampel uji widal tabung negatif setelah dilakukan pemeriksaan PCR (Polimerase Chain Reaction) Salmonella typhi 12 sampel Salmonella typhi, yaitu titer $1 / 20$ sebanyak 3 sampel, titer $1 / 40$ sebanyak 4 sampel dan titer $1 / 80$ sebanyak 5 sampel. Didapatkan pula 8 sampel titer 1/20, 1/40, 1/80 Salmonella typhi negatif. Hasil penelitian sebagai berikut :

Tabel 2. Persentase Hasil

Pemeriksaan Widal Tabung titer $0 \leq 1 / 80$ dan pemeriksaan PCR

\begin{tabular}{cccccc}
\hline \multirow{2}{*}{$\begin{array}{c}\text { Widal } \\
\text { tabung }\end{array}$} & \multirow{2}{*}{$\begin{array}{c}\text { Jumlah } \\
\text { (Titer) }\end{array}$} & \multicolumn{4}{c}{ PCR } \\
sampel & & Salmonella & typhi \\
\cline { 3 - 6 } & & $\mathbf{4}$ & $\%$ & - & $\mathbf{\%}$ \\
\hline $1 / 20$ & 4 & 3 & 75 & 1 & 25 \\
140 & 8 & 4 & 50 & 4 & 50 \\
$1 / 80$ & 8 & 5 & 63.5 & 3 & 37.5 \\
Total & 20 & 12 & 60 & 6 & 40 \\
\hline
\end{tabular}

\section{PEMBAHASAN}

Dari hasil pemeriksaan $\mathrm{Uji}$ Widal negatif yaitu titer $1 / 20, / 1 / 40,1 / 80$ dan setelah dilakukan pemeriksaan PCR terhadap ketiga sampel tersebut dengan hasil PCR Salmonella typhi positif dapat disebabkan beberapa hal, antara lain adalah tidak dihasilkannya antibodi terhadap Salmonella karena rendahnya stimulus yang dapat merangsang timbulnya antibodi sehingga produksi antibodi terganggu. Keadaan umum yang menyebabkan terhambatnya pembentukan antibodi adalah status gizi yang buruk (Karacabey \& Ozdemir, 2012).

Kemudian pengambilan spesimen yang dilakukan pada minggu pertama demam, sehingga titer antibodi belum terdeteksi. Hal ini didukung oleh penelitian Senewiratne, dkk yang menyatakan kenaikan titer antibodi ke tingkat diagnostik pada uji Widal umumnya paling baik pada minggu kedua atau ketiga.(Senewiratne \& Senewiratne, 1977) Karena itu bila infeksi baru berlangsung beberapa hari, seringkali hasilnya masih negatif dan baru akan positif bila pemeriksaan diulang. Dengan demikian hasil uji Widal negatif terutama beberapa hari pertama demam belum dapat menyingkirkan kemungkinan demam tifoid.(Mihiretie Mengist \& Tilahun, 2017)

Pada pengambilan menggunakan spesimen tunggal, tidak dapat melihat adanya kenaikan titer. Sehingga pemeriksaan widal memerlukan dua kali 
pengambilan spesimen, yaitu pada masa akut dan konvalesens dengan interval waktu 10-14 hari.(Wain \& Hosoglu, 2008) Nilai diagnostik uji Widal adalah melihat adanya kenaikan titer yang bermakna dalam darah terhadap antigen $\mathrm{O}$ dan atau antigen $\mathrm{H}$ Salmonella typhi pada 2 kali pengambilan spesimen akut ke konvalesens.(Willke, Ergonul, \& Bayar, 2002)

Adanya variabilitas reagen yang digunakan, sensitifitas terutama spesifisitas uji widal sangat dipengaruhi oleh jenis antigen yang digunakan. Uji Widal yang menggunakan antigen yang dibuat dari jenis strain kuman asal daerah endemis (lokal) memberikan sensitifitas dan spesifisitas yang secara bermakna lebih tinggi danpada antigen yang berasal dari strain kuman asal luar daerah endemis.(Mihiretie Mengist \& Tilahun, 2017)

Sampel yang digunakan dalam uji Widal adalah serum, aglutinin yang spesifik terhadap Salmonella typhi terdapat dalam serum penderita dengan demam tifoid dan juga terdapat pada orang yang pernah divaksinasi. Uji Widal tabung dinyatakan positif bila titer antibodi $1 / 160$ baik untuk aglutinin $O$ maupun $\mathrm{H}$ dengan kriteria diagnostik tunggal atau terdapat kenaikan titer 4 kali atau lebih dengan selang waktu satu minggu kemudian. Sedangkan widal tabung negatif bila titer antibodi $\mathrm{O}$ $\leq 1 / 80$. Adapun kelemahan dari Uji Widal antara lain sensitifitas, spesifisitas dan interpretasi hasil yang berbeda dipengaruhi oleh endemisitas masingmasing daerah.(Senewiratne \& Senewiratne, 1977)

Dalam penelitian ini dilakukan pemeriksaan Polimerase Chain Reaction (PCR) Salmonella typhi. Pada cara ini dilakukan perbanyakan DNA kuman yang diidentifikasi dengan primer yang spesifik. Beberapa penelitian melaporkan bahwa nilai sensitifitas PCR Salmonella typhi lebih dari 90\%, 95\%, $90,48 \%$ in vivo dan spesifisitas $100 \%$ in vitro.(Storey et al., 2015) Kelebihan uji ini dapat mendeteksi kuman dalam jumlah sedikit sangat sensitif, spesifik, cukup cepat dan tidak terpengaruh oleh pemberian antibiotik sebelumnya. Kendala yang sering dihadapi pada penggunaan metode PCR ini meliputi resiko kontaminasi yang menyebabkan hasil positif palsu yang terjadi bila prosedur teknis tidak dilakukan dengan cermat, adanya bahan-bahan dalam spesimen yang bisa menghambat proses PCR yaitu Hemoglobin dan Heparin dalam sampel darah.(Djordjevic \& Stankovic, 2006)

Kejadian positif palsu juga sering dikaitkan dengan kenyataan bahwa PCR dapat memberikan hasil positif tanpa membedakan kuman hidup maupun mati. Dalam hal ini, dukungan gejala klinis sangat penting untuk menghindari positif palsu tersebut.

Penggunaan EDTA juga dapat memperkecil terjadinya kontaminasi pada hasil PCR dibandingkan dengan penggunaan Heparin pada konsentrasi yang sama. Pemeriksaan dengan metode PCR kurang terpengaruh oleh faktor-faktor yang berhubungan dengan pembentukan antibodi dan pemakaian antibiotik, namun saat ini tidak semua laboratorium menyediakan pemeriksaan ini, karena teknik yang rumit dan biaya yang relatif mahal sehingga pemakaian lebih banyak digunakan dalam lingkup penelitian.

\section{KESIMPULAN}

Dari hasil penelitian ini ada perbedaan bermakna antara hasil pemeriksaan uji Widal tabung negatif yaitu titer $\mathrm{O} \leq 1 / 80$ dengan pemeriksaan PCR (Polimerase Chain Reaction), hal ini membuktikan bahwa metode PCR mempunyai sensitifitas dan spesifisitas lebih tinggi dibandingkan dengan uji Widal Tabung dan menggunakan spesimen tunggal.

PCR yang selama ini lebih banyak digunakan terbatas dalam lingkup penelitian diharapkan kedepannya dapat digunakan sebagai salah satu alat diagnostik rutin penyakit demam tifoid.

\section{DAFTAR PUSTAKA}

Alba, S., Bakker, M. I., Hatta, M., \& Scheelbeek, P. F. D. (2016). Risk Factors of Typhoid Infection in the Indonesian Archipelago. PLOS 
ONE, $\quad 11(6), \quad 1-14$.

https://doi.org/10.1371/journal. pone.0155286

Ayub, U., Khattak, A. A., Saleem, A., Javed, F., Siddiqui, N., Hussain, N., \& Hayat, A. (2015). Incidence of Typhoid Fever in Islamabad City. American-Eurasian Journal of Toxicological Sciences, 7(4), 220223.

https://doi.org/10.5829/idosi.aejts. 2015.7.4.95188

Buckle, G. C., Walker, C. L. F., Black, R. E., \& Walker, C. L. F. (2012). Typhoid fever and paratyphoid fever: Systematic review to estimate global morbidity and mortality for 2010 Correspondence to : $\quad 2(1), \quad 1-9$. https://doi.org/10.7189/jogh.02.01 0401

Choerunnisa, N., Tjiptaningrum, A., \& Basuki, W. (2014). Proportion of Positive Igm Anti Salmonella Typhi 09 Examination Using Tubex With Positive Widal Examination In Clinical Patient of Acute Typhoid Fever In Dr. H. Abdul Moeloek Hospital Bandar Lampung. Medical Journal of Lampung University, 3(1), 102-110.

Crump, J. A., \& Mintz, E. D. (2011). Global trends in typhoid and paratyphoid fever. Clin Infect Dis, 50(2), 241-246. https://doi.org/10.1086/649541.GI obal

Djordjevic, V., \& Stankovic, M. (2006). PCR amplification on whole blood samples treated with different commonly used anticoagulants. Pediatric Hematology and Oncology, 23(7), 517-521. https://doi.org/10.1080/08880010 600751900

Karacabey, K., \& Ozdemir, N. (2012). Obesity \& Weight Loss Therapy. Obesity \& Weight Loss Therapy, 2(9), https://doi.org/10.4172/21657904.1000152

Marleni, M., Iriani, Y., \& Tjuandra, W. (2014). Ketepatan Uji Tubex TF $\AA$ dalam Mendiagnosis Demam Tifoid Anak pada Demam Hari ke-4.
Jurnal Kedokteran Dan Kesehatan, 1(1), 7-11.

Mihiretie Mengist, $\mathrm{H}$. , \& Tilahun, K. (2017). Diagnostic Value of Widal Test in the Diagnosis of Typhoid Fever: A Systematic Medical Microbiology \& Diagnosis Diagnostic Value of Widal Test in the Diagnosis of Typhoid Fever: A Systematic Review. Medical Microbiology \& DiagnosisISSN, 6(1), 2-4. https://doi.org/10.4172/21610703.1000248

Ochiai, R. L., Acosta, C. J., Danovaroholliday, M. C., Baiqing, D., Bhattacharya, S. K., Agtini, M. D., ... Galindo, C. M. (2008). A study of typhoid fever in five Asian countries: disease burden and implications for controls. Bulletin of the World Health Organization, 82(5), 346-353. https://doi.org/10.2471/BLT.06.03 9818

Senewiratne, B., \& Senewiratne, K. (1977). Reassessment Of The Widal Test In The Diagnosis Of Typhoid. Gastroenterology, 73(2), 233-236. https://doi.org/10.1016/S00165085(19)32194-8

Septiawan, I. K., Herawati, S., \& Yasa, I. W. P. S. (2013). Pemeriksaan Immunoglobulin M Anti Salmonella Dalam Diagnosis Demam Tifoid. EJurnal Medika Udayana, 2(6), 1080-1190.

Setiana, G. P. (2016). Perbandingan Metode Diagnosis Demam Tifoid. Farmaka, 4(1), 94-103.

Storey, H. L., Huang, Y., Crudder, C., Golden, A., \& Santos, T. D. L. (2015). A Meta-Analysis of Typhoid Diagnostic Accuracy Studies: A Recommendation to Adopt a Standardized Composite Reference. PLOS ONE, 10(11), 1-24. https://doi.org/10.1371/journal.po ne.0142364

Sucipta, A. A. M. (2015). Baku Emas Pemeriksaan Laboratorium Demam Tifoid Pada Anak. Jurnal Skala Husada, 12(1), 22-26.

Wain, J., \& Hosoglu, S. (2008). The laboratory diagnosis of enteric fever. $J$ Infect Developing 
Countries, 2(6), 10-15.

https://doi.org/10.3855/jidc.155

Willke, A., Ergonul, O., \& Bayar, B. (2002). Widal Test in Diagnosis of Typhoid Fever in Turkey. Clinical And Diagnostic Laboratory Immunology, 9(4), 938-941. https://doi.org/10.1128/CDLI.9.4.9 38

World Health Organization. (2003). Background document The diagnosis,treatment and prevention of typhoid fever. 